\title{
Non-Target Site Mechanisms Endow Resistance to Glyphosate in Saltmarsh Aster (Aster squamatus)
}

\author{
José Alfredo Domínguez-Valenzuela ${ }^{1, *}$, Ricardo Alcántara-de la Cruz ${ }^{2, *} \mathbb{C}^{\circ}$, Candelario Palma-Bautista ${ }^{3}(\mathbb{D}$, \\ José Guadalupe Vázquez-García ${ }^{3}$ (i), Hugo E. Cruz-Hipolito ${ }^{3}$ and Rafael De Prado ${ }^{3}$ (i) \\ 1 Departamento de Parasitología Agrícola, Universidad Autónoma Chapingo, Texcoco 56230, Mexico \\ 2 Centro de Ciências da Natureza, Universidade Federal de São Carlos-Campus Lagoa do Sino, \\ Buri 18290-000, Brazil \\ 3 Department of Agricultural Chemistry, Edaphology and Microbiology, University of Córdoba, \\ 14014 Córdoba, Spain; z82pabac@uco.es (C.P.-B.); z82vagaj@uco.es (J.G.V.-G.); \\ cruzhipolito@yahoo.com.mx (H.E.C.-H.); qe1pramr@uco.es (R.D.P.) \\ * Correspondence: jose_dv001@yahoo.com.mx (J.A.D.-V.); ricardo.cruz@ufscar.br (R.A.-d.1.C.)
}

check for updates

Citation: Domínguez-Valenzuela, J.A.; Alcántara-de la Cruz, R.; Palma-Bautista, C.; Vázquez-García, J.G.; Cruz-Hipolito, H.E.; De Prado, R. Non-Target Site Mechanisms Endow Resistance to Glyphosate in Saltmarsh Aster (Aster squamatus). Plants 2021, 10, 1970. https:// doi.org/10.3390/plants10091970

Academic Editor: Hudson Takano

Received: 26 August 2021

Accepted: 17 September 2021

Published: 21 September 2021

Publisher's Note: MDPI stays neutral with regard to jurisdictional claims in published maps and institutional affiliations.

Copyright: (c) 2021 by the authors. Licensee MDPI, Basel, Switzerland. This article is an open access article distributed under the terms and conditions of the Creative Commons Attribution (CC BY) license (https:/ / creativecommons.org/licenses/by/ $4.0 /)$.

\begin{abstract}
Of the six-glyphosate resistant weed species reported in Mexico, five were found in citrus groves. Here, the glyphosate susceptibility level and resistance mechanisms were evaluated in saltmarsh aster (Aster squamatus), a weed that also occurs in Mexican citrus groves. The $\mathrm{R}$ population accumulated 4.5-fold less shikimic acid than S population. S plants hardly survived at $125 \mathrm{~g}$ ae ha $\mathrm{ha}^{-1}$ while most of the R plants that were treated with $1000 \mathrm{~g}$ ae ha ${ }^{-1}$, which suffered a strong growth arrest, showed a vigorous regrowth from the third week after treatment. Further, 5-enolpyruvylshikimate3-phosphate basal and enzymatic activities did not diverge between populations, suggesting the absence of target-site resistance mechanisms. At $96 \mathrm{~h}$ after treatment, R plants absorbed $\sim 18 \%$ less glyphosate and maintained $63 \%$ of the ${ }^{14} \mathrm{C}$-glyphsoate absorbed in the treated leaf in comparison to $\mathrm{S}$ plants. R plants metabolized twice as much (72\%) glyphosate to amino methyl phosphonic acid and glyoxylate as the $\mathrm{S}$ plants. Three non-target mechanisms, reduced absorption and translocation and increased metabolism, confer glyphosate resistance saltmarsh aster. This is the first case of glyphosate resistance recorded for A. squamatus in the world.
\end{abstract}

Keywords: aminomethylphosphonic acid; glyphosate metabolism; impaired translocation; phoenix phenomenon; reduced absorption

\section{Introduction}

Glyphosate is the active ingredient in numerous trade formulation herbicides for nonselective postemergence control of both annual and perennial weeds [1]. This herbicide disrupts the biosynthesis of tryptophan, phenylalanine and tyrosine by interrupting the activity of the enzyme 5-enolpyruvylshikimate-3-phosphate synthase (EPSPS) [2]. Glyphosate is used to control all types of annual and perennial weeds [3], being the main weed control tool in citrus groves in Veracruz, Mexico [4].

With more than 593,000 ha planted with citrus, mainly located in the state of Veracruz [5], Mexico is the fourth largest producer of citrus fruits worldwide [6], however, it is the main exporter of limes [7]. Citrus groves, particularly in the Gulf of Mexico, are subject to a heavy use of glyphosate [8], since rarely preemergent herbicides are used and other postemergence ingredients increase weed control costs [4]. As a result of basing weed control almost exclusively on glyphosate, some weed species evolved resistance to glyphosate. Of the six weed species reported to be resistant to glyphosate in Mexico, five were found in citrus groves [9].

Recently another weed species, common in citrus groves in the municipalities of Martinez de la Torre and San Rafael, Veracruz, has shown low levels of control with overdoses of 3-4 $\mathrm{L} \mathrm{ha}^{-1}$ of commercial formulations of glyphosate $\left(362 \mathrm{~g}\right.$ ae $\left.\mathrm{L}^{-1}\right)$, considering that 
the recommended field dose is $720 \mathrm{~g}$ ae ha ${ }^{-1}$ [4]. Saltmarsh aster, Aster squamatus (Spreng.) Hieron. (Synonim: Symphyotrichum squamatum (Spreng) G. L. Nesom (Asteraceae), an annual weed native to South America but currently its distribution has extended to Asia, Europe, and North America [10,11], is one of the weed species that has not been efficiently controlled with glyphosate. Saltmarsh aster is found along the eastern coastal region of the Gulf Coast of Mexico [12], so it is a common weed occurring in citrus groves in the State of Veracruz. Seedling have broad leaves arranged in a rosette, and as the stem grows up, leaves tend to be narrow; plants height can be of up to $2 \mathrm{~m}$ [12].

For a better agricultural production in the presence of herbicide resistant weeds, it is essential to characterize the resistance mechanisms, since knowing such mechanisms contributes to implementing better weed management strategies. Fifty-one weeds have evolved resistance to glyphosate in the world [13], showing a great diversity of mechanisms endowing that resistance [14]. Replacement of amino acids at key positions in conserved regions of the EPSPS encoding gene, or EPSPS gene amplification inducing the overexpression of this enzyme are called target-site resistance (TSR) mechanisms. Physiological or metabolically responses such as the reduced absorption, impaired translocation, herbicide metabolism, vacuolar sequestration of glyphosate and, recently characterized foliar hypersensitivity that diminishes the amount of herbicide that reaches the EPSPS are called non-target site resistance (NTSR) mechanisms [15,16].

Saltmarsh aster has no official records of herbicide resistance in the International Herbicide-Resistant Weed Database [13], but it was reported with resistance to imazethapyr in Seville, Spain [17]. This present study was carried out to confirm the resistance to glyphosate in saltmarsh aster, a common weed in the citrus groves of Veracruz, Mexico, that has been poorly controlled with this herbicide in recent growing cycles, and to characterize its resistance mechanisms.

\section{Results}

\subsection{Resistance Confirmation to Glyphosate}

Both saltmarsh aster populations showed high growth reduction showing low $\mathrm{GR}_{50}$ (herbicide rate that reduces plant growth by $50 \%$ ) values (Figure 1A). The susceptible (S) population was highly susceptible to glyphosate $\left(\mathrm{GR}_{50}=14.7 \mathrm{~g}\right.$ ae ha-1); however, the resistant $(\mathrm{R})$ population was 13 -fold more resistant. The $\mathrm{R}$ population presented an $\mathrm{LD}_{50}$ (herbicide rate that kills $50 \%$ of the plant in a population) of $2078.1 \mathrm{~g}$ ae ha ${ }^{-1}$, which exceeded the field dose used in citrus groves $\left(720 \mathrm{~g}\right.$ ae ha $\left.-{ }^{1}\right)$, while all $\mathrm{S}$ plants died from glyphosate doses of $250 \mathrm{~g}$ ae ha ${ }^{-1}$. Based on the $\mathrm{LD}_{50}$ values, the R population presented a $\mathrm{RF}$ of 9.7 with respect to the $S$ population (Figure 1B, Table 1 ). S plants hardly survived at $125 \mathrm{~g}$ ae ha ${ }^{-1}$; whereas most of the $\mathrm{R}$ plants survived up to $2000 \mathrm{~g}$ ae ha ${ }^{-1}$ (Figure 1C). $\mathrm{R}$ plants treated with $1000 \mathrm{~g}$ ae ha ${ }^{-1}$ suffered a growth arrest, but from 4 week after treatment displayed a vigorous regrowth (Figure 1D). 

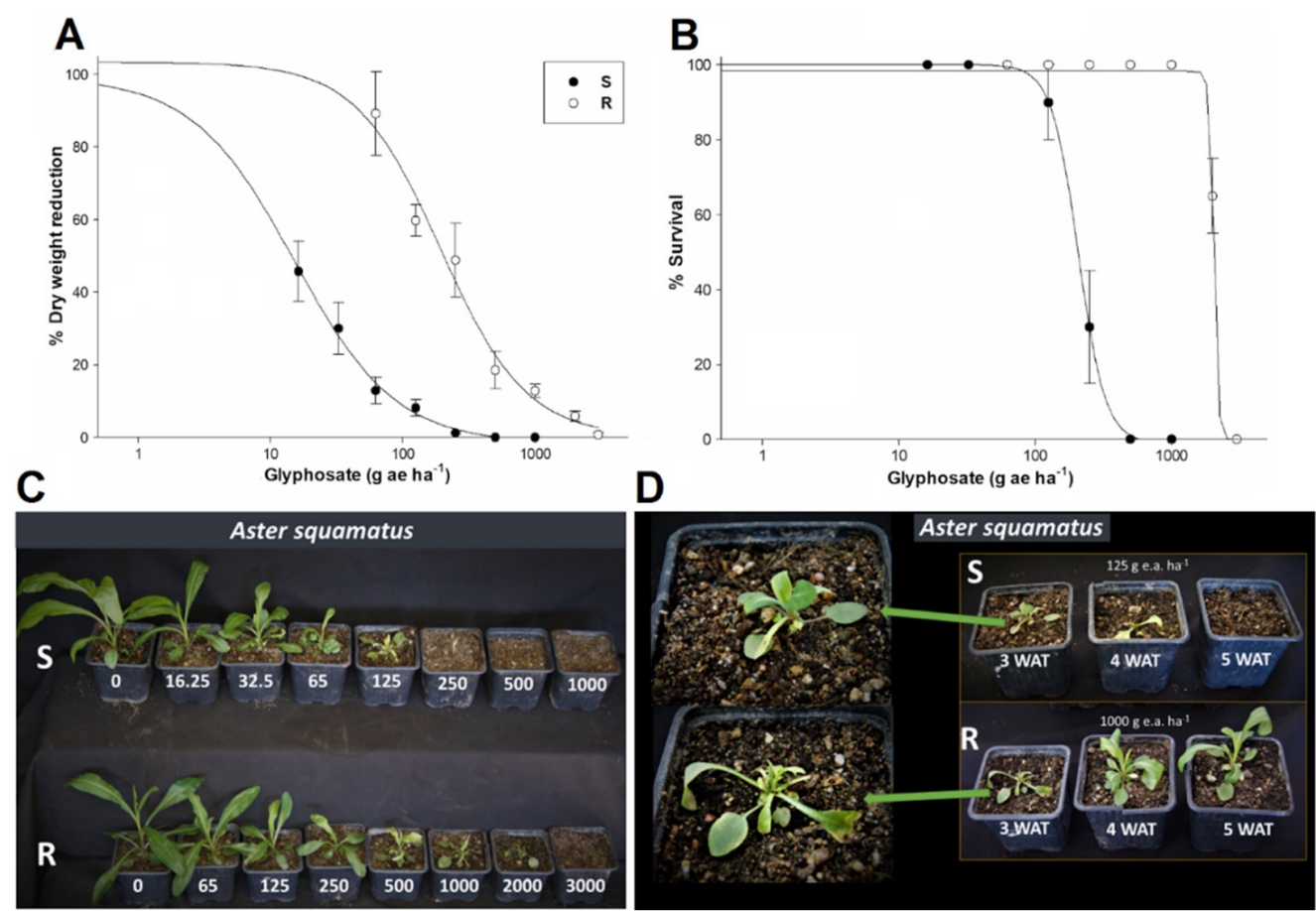

Figure 1. Glyphosate dose-response curves of the dry weight reduction (A) and plant survival (B) in susceptible (S) and resistant (R) saltmarsh aster (A. squamatus) populations treated with different glyphosate doses (g ae ha $\left.{ }^{-1}\right)$. Vertical bars are the SEM $(n=10$ for weight reduction and $n=2$ for plant survival). (C) R and S plants at 4 weeks after treatment (WAT) of glyphosate. (D) Regrowth of $\mathrm{S}$ and $\mathrm{R}$ plants treated with 125 and $1000 \mathrm{~g}$ ae ha ${ }^{-1}$ glyphosate, respectively, at different WATs.

Table 1. Parameters of the three-parameter log-logistic equation a used to estimate the weight reduction, plant mortality or enzyme activity inhibition by $50 \%$ in glyphosate-susceptive (S) and -resistant (R) saltmarsh aster populations.

\begin{tabular}{|c|c|c|c|c|c|}
\hline Dose-Response & Population & $b$ & $d$ & $g$ & RF \\
\hline \multirow{2}{*}{$\begin{array}{l}\text { Weight reduction } \\
\quad\left(\mathrm{g} \text { ae ha }{ }^{-1}\right)\end{array}$} & $S$ & 1.2 & 99.9 & $14.7 \pm 1.2$ & \multirow[b]{2}{*}{13.7} \\
\hline & $\mathrm{R}$ & 1.3 & 101.1 & $202.1 \pm 17.2$ & \\
\hline \multirow{2}{*}{$\begin{array}{l}\text { Plant mortality } \\
\qquad\left(\mathrm{g} \text { ae ha }{ }^{-1}\right)\end{array}$} & $S$ & 5.5 & 100.0 & $214.3 \pm 11.4$ & \multirow[b]{2}{*}{9.7} \\
\hline & $\mathrm{R}$ & 7.1 & 99.9 & $2078.1 \pm 60.9$ & \\
\hline \multirow{2}{*}{$\begin{array}{l}\text { Enzyme inhibition } \\
\qquad(\mu \mathrm{M})\end{array}$} & $S$ & 0.2 & 99.6 & $0.27 \pm 0.04$ & \multirow{2}{*}{0.85} \\
\hline & $\mathrm{R}$ & 4.2 & 100.5 & $0.23 \pm 0.02$ & \\
\hline
\end{tabular}

${ }^{\text {a }} \mathrm{Y}=d /\left[1+(x / g)^{b}\right]$, where $\mathrm{Y}$ is the percentage weight reduction, plant mortality or enzyme activity in comparison to the respective nontreated control, $d$ is the upper asymptote of the curve, $b$ is the slope of the curve, $g$ is the inflection point of the curve halfway (GR 50 , $\mathrm{LD}_{50}$ or $\left.\mathrm{I}_{50}\right)$, and $\mathrm{x}$ is the herbicide dose tested. Resistance factors $(\mathrm{RF}=\mathrm{R} / \mathrm{S})$ are the $\mathrm{R}$-to-S $\mathrm{LD}_{50}, \mathrm{ED}_{50}$ or $\mathrm{I}_{50}$ ratios.

\subsection{Acummulation of Shikimic Acid}

The two saltmarsh aster populations presented shikimic acid accumulation, but the $\mathrm{S}$ population accumulated more shikimate than $\mathrm{R}$ population, regardless of glyphosate concentration. The accumulation ranged from 0.1 to $5 \mu \mathrm{g}$ shikimic acid $\mathrm{mL}^{-1}$ as glyphosate concentration increased in the population $R$, while in the population $S$ it went from 4 to $20.5 \mu \mathrm{g}$ shikimic acid $\mathrm{mL}^{-1}$ (Figure 2). 


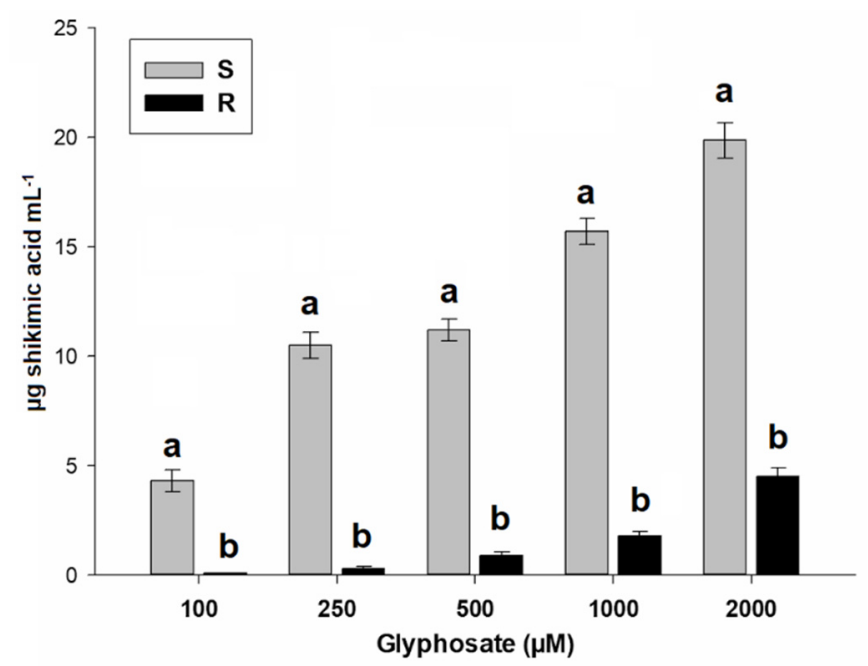

Figure 2. Accumulation of shikimic acid accumulation induced by glyphosate in susceptible (S) and resistant (R) saltmarsh aster populations (A. squamatus) found in Persian lime groves from Veracruz, Mexico. Vertical bars represent the standard error of the mean $(n=6)$. Different letter denotes differences between populations within a glyphosate by the Tukey test $(p<0.05)$.

\subsection{Concentration and Activity of the EPSPS}

EPSPS basal and enzymatic activities of both saltmarsh aster populations showed no statistical differences. EPSPS activities of the $S$ and R populations were 0.64 and $0.59 \mu \mathrm{mol}$ of inorganic phosphate $(\mathrm{Pi})$ released per $\mu \mathrm{g}$ of total soluble protein (TSP) per min $(\mu \mathrm{mol}$ $\mathrm{Pi} \mu \mathrm{g}^{-1}$ TSP $\mathrm{min}^{-1}$ ), respectively, and only $\sim 0.25 \mu \mathrm{M}$ of glyphosate inhibited the EPSPS activity by $50 \%$ in both populations (Figure 3 , Table 1 ).

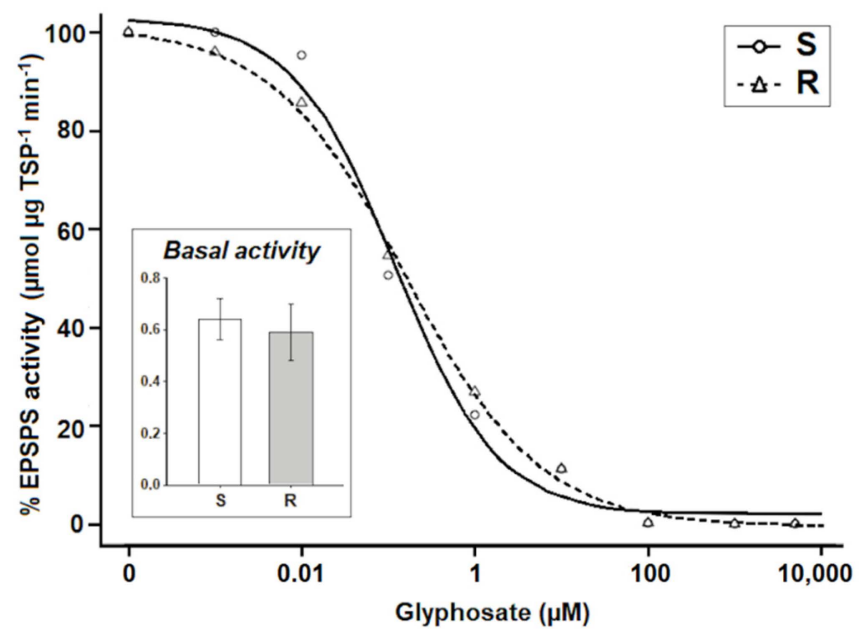

Figure 3. Enzyme activity of the 5-enolpyruvilshikimate-3-phosphate synthase (EPSPS) in glyphosatesusceptible (S) and -resistant (R) saltmarsh aster (A. squamatus) populations.

\subsection{Absorption and Translocation of ${ }^{14} \mathrm{C}$-Glyphosate}

The absorption of ${ }^{14} \mathrm{C}$-glyphosate increased from 15 to $53 \%$, depending on the saltmarsh aster population, between 12 and $96 \mathrm{~h}$ after treatment (HAT). At short evaluation times there was no differences in absorption between populations, but from $72 \mathrm{HAT}$, population $\mathrm{S}$ absorbed between 12 and $18 \%$ more ${ }^{14} \mathrm{C}$-glyphosate than the $\mathrm{R}$ population, (Figure $4 \mathrm{~A}$ ), according to the ${ }^{14} \mathrm{C}$ signals detected by liquid scintillation spectrometry (LSS). Qualitatively, a large amount of ${ }^{14} \mathrm{C}$ from ${ }^{14} \mathrm{C}$-glyphosate remained in the treated leaves of the two populations, but the $S$ one translocated more ${ }^{14} \mathrm{C}$ to the roots than $\mathrm{R}$ population (Figure $4 \mathrm{~B}$ ). The population $\mathrm{S}$ translocated more ${ }^{14} \mathrm{C}$ of the absorbed ${ }^{14} \mathrm{C}$-glyphosate to 
the remainder of the plant and root system than the R population from $24 \mathrm{HAT}$, and the differences increased over time, observing the greatest difference $(18 \%)$ between populations at 96 HAT. The signals of ${ }^{14} \mathrm{C}$ detected in the rest of the plant increased gradually from 14 to $27 \%$ with the passage of time, but did not differ between populations. However, the amount of ${ }^{14} \mathrm{C}$-herbicide that reached the roots, that ranged from to 4 to $32 \%$, differed between populations from $24 \mathrm{HAT}$, always being higher in population S, and at $96 \mathrm{HAT}$, there was $15 \%$ more glyphosate in roots of $S$ plants than in those of the $R$ (Figure $4 C$ ).
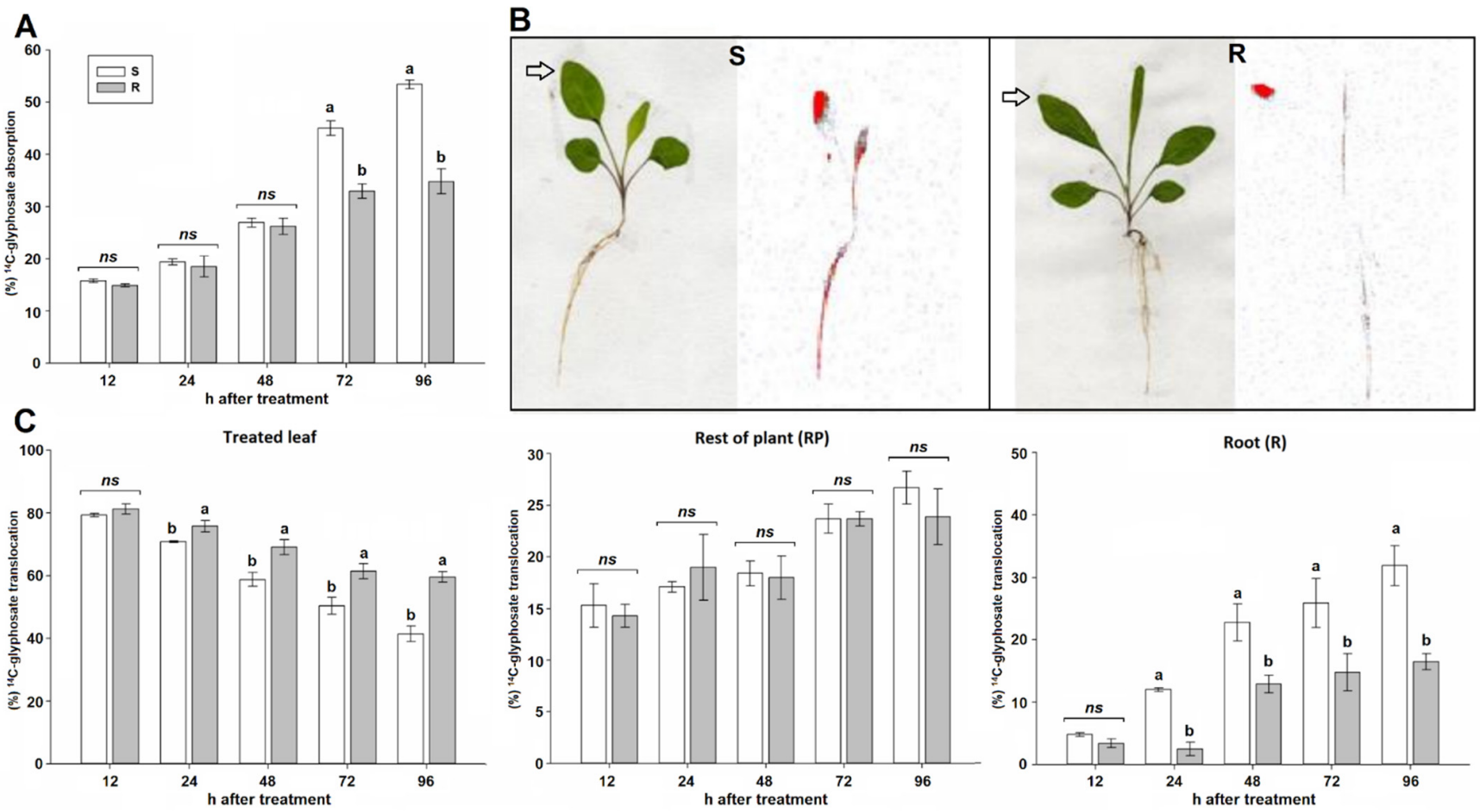

Figure 4. Absorption and translocation of ${ }^{14} \mathrm{C}$-glyphosate in susceptible (S) and resistant (R) saltmarsh aster (A. squamatus) populations from 12 to $96 \mathrm{~h}$ after treatment (HAT). (A) ${ }^{14} \mathrm{C}$-glyphosate absorption (\% from the total applied). (B) Digital (on the left) and autoradiograph (right) images illustrating the ${ }^{14} \mathrm{C}$-glyphosate distribution within plants at 96 HAT. Red regions show higher signal (concentration) of ${ }^{14} \mathrm{C}$. (C) ${ }^{14} \mathrm{C}$-glyphosate translocation (\% of the recovered) from the treated leaf to the rest of the plant, and roots. Vertical bars represent the standard error of the mean $(n=5)$. ns, no significant and different letter denotes differences between populations within an evaluation time by the Tukey test $(p<0.05)$.

\subsection{Glyphosate Metabolism}

Aminomethylphosphonic acid (AMPA) and glyoxylate are metabolites in which glyphosate can be metabolized by most higher plants [18]. Saltmarsh aster $\mathrm{S}$ and $\mathrm{R}$ plants metabolized up to 48 and $85 \%$ of glyphosate, respectively. The amounts of glyphosate, AMPA and glyoxylate found above-ground plant tissue ranged from 30 to 60, 4 to 37 and 4 to $39 \mathrm{nmol} \mathrm{g}^{-1}$ fresh weight, respectively, depending on the population and evaluation time. The $S$ plants transformed between 7 and $19 \%$ of the glyphosate into AMPA and between 6 and 17\% in glyoxylate from 48 to 96 HAT; while R plants metabolized between 18 and $35 \%$ in AMPA, and from 17 to $37 \%$ in glyoxylate over time (Table 2). 
Table 2. Amount of glyphosate and metabolites ( $\mathrm{nmol} \mathrm{g}^{-1}$ fresh weight) in resistant (R) and susceptible (S) saltmarsh aster populations at different hours after treatment (HAT) with $720 \mathrm{~g}$ ae ha ${ }^{-1}$ of glyphosate.

\begin{tabular}{ccccc}
\hline HAT & Population & Glyphosate & AMPA $^{*}$ & Glyoxylate \\
\hline \multirow{2}{*}{48} & $\mathrm{~S}$ & $53.3 \pm 4.2(87) \mathrm{a}$ & $4.4 \pm 0.8(7) \mathrm{b}$ & $3.9 \pm 0.6(6) \mathrm{b}$ \\
& $\mathrm{R}$ & $45.5 \pm 3.8(65) \mathrm{b}$ & $12.6 \pm 2.0(18) \mathrm{a}$ & $11.7 \pm 1.9(17) \mathrm{a}$ \\
\hline \multirow{2}{*}{72} & $\mathrm{~S}$ & $57.7 \pm 4.7(73) \mathrm{a}$ & $11.2 \pm 1.4(14) \mathrm{b}$ & $10.1 \pm 1.2(13) \mathrm{b}$ \\
& $\mathrm{R}$ & $43.6 \pm 3.6(50) \mathrm{b}$ & $22.3 \pm 2.2(26) \mathrm{a}$ & $21.1 \pm 3.1(24) \mathrm{a}$ \\
\hline \multirow{2}{*}{96} & $\mathrm{~S}$ & $59.8 \pm 4.6(64) \mathrm{a}$ & $18.1 \pm 1.8(19) \mathrm{b}$ & $16.3 \pm 2.3(17) \mathrm{b}$ \\
& $\mathrm{R}$ & $30.1 \pm 2.6(28) \mathrm{b}$ & $37.3 \pm 4.1(35) \mathrm{a}$ & $39.8 \pm 4.3(37) \mathrm{a}$ \\
\hline
\end{tabular}

${ }^{*}$ Aminomethylphosphonic acid. Means \pm SE (relative \%). Different letter denotes differences between populations within an evaluation time by the Tukey test $(p<0.05)$.

\section{Discussion}

The $S$ and $R$ saltmarsh aster populations from Mexico showed contrasting susceptibility levels to glyphosate. Plants of population R had a 50\% of weight reduction with $200 \mathrm{~g}$ ae ha ${ }^{-1}$, but most of them survived at doses of up to $2000 \mathrm{~g}$ ae ha ${ }^{-1}$, which is a glyphosate concentration well above the field dose of $720 \mathrm{~g}_{\text {ae }} \mathrm{ha}^{-1}$ widely used in citrus groves of the Gulf Coast of Mexico [4]. This plant survival rate confirms farmers complaints about poor control of saltmarsh aster with glyphosate, supporting the hypothesis of selection of resistant individuals. In addition, resistance ratios were 13.7 and 9.7 with respect to weight reduction and plant survival, respectively. $S$ population of another Asteraceae weed species found in citrus groves in the same area of the Gulf Coast of Mexico, such as Bidens pilosa and Parthenium hysterophorus, were greatly sensitive to glyphosate $\left(\mathrm{GR}_{50}\right.$ values of 52 and $43 \mathrm{~g}_{\text {ae }} \mathrm{ha}^{-1}$, respectively), while some $\mathrm{R}$ plants of both species also survived at doses higher that $2000 \mathrm{~g}_{\text {ae }} \mathrm{ha}^{-1}[19,20]$.

In addition to poor saltmarsh aster control, farmers also reported a vigorous regrowth of the treated plants starting in the third week after glyphosate had apparently compromised their development. That field observation was corroborated in this study, where $S$ plants treated with $125 \mathrm{~g}$ ae ha ${ }^{-1}$ died or hardly survived, while $\mathrm{R}$ plants survived and regrew even at $2000 \mathrm{~g}$ ae ha ${ }^{-1}$. Regrowth was previously documented for glyphosateresistant Ambrosia trifida, another Asteraceae weed [21,22]. However, different to saltmarsh aster, giant ragweed presented a rapid necrosis and death of leaf tissue in the first 48 HAT followed by vigorous regrowth and, at 3 WAT, the treated R plants already had a normal appearance [16], for which this regrowth was called "phoenix phenomenon" [21]. Similar to A. trifida, Conyza sumatrensis from Brazil also presented rapid necrosis followed by a regrowth after 2,4-D treatment [23]. In both species, the mechanism that induced rapid necrosis is not fully understood, but it was suggested that cell death was due to the high production and action of reactive oxygen species (ROS), preventing the translocation of herbicides to apical growing meristems [21,23]. ROS production levels were not determined in saltmarsh aster populations, and due to the longer time that $\mathrm{R}$ plants took to restart growth, it is unlikely that the phoenix phenomenon was responsible for regrowth in this population. Additional studies are required to characterize the mechanisms that enable vigorous regrowth of $\mathrm{R}$ saltmarsh aster plants.

The accumulation of shikimic acid, widely used as a bioindicator of the level of susceptibility to glyphosate [24], confirmed the resistance of the R saltmarsh aster population that accumulated 4.5 times less shikimate than the S population, showing little or limited interaction of the glyphosate with the EPSPS [25]. However, shikimic acid accumulation tests do not reveal which type of TSR or NTSR mechanism confer resistance [26]. In this sense, enzymatic activity assays of herbicide target enzymes are important to reveal a possible involvement of TSR mechanisms [27]. However, TSR mechanisms such as EPSPS mutations or EPSPS gene amplification was ruled out in the R saltmarsh aster population, because their EPSPS basal and enzymatic activities did not diverge with respect to the $S$ 
population. Thus, mechanism (s) endowing resistance to glyphosate in the population $\mathrm{R}$ was restricted to NTSR.

Absorption and translocation of ${ }^{14} \mathrm{C}$-glyphosate by $\mathrm{R}$ saltmarsh aster plants was lower than in $\mathrm{S}$ saltmarsh aster plants. Foliar herbicide absorption differences between $\mathrm{R}$ and $\mathrm{S}$ plants have been linked to anatomical characteristics of the leaves [14], such as leaf cuticle, trichome distribution, growth stage and leaf structure [28,29]. Reduced absorption is a rare herbicide resistance mechanism and has been documented in several weed species resistant to glyphosate such as Amaranthus tuberculatus [30], Lolium multiflorum [31], Sorghum halepense [32], to mention some cases, as well as to other herbicides [33]. However, how plants diminish herbicide absorption rates is not fully understood. The R saltmarsh aster plants absorbed less glyphosate than S plants, which somehow allows them to survive higher doses of herbicide.

Systemic herbicides such as glyphosate must be translocated to apical growing meristems to reach its target site in sufficient amounts to act and be lethal to weeds [34]. Given that the movement of ${ }^{14} \mathrm{C}$-glyphosate from the treated leaves to the rest of the plants and roots was limited for the R saltmarsh aster plants, adding to this that this population also absorbed less herbicide, it can be assumed that the amount of glyphosate that reached the EPSPS was not enough to completely inhibit it. Reduced translocation may occur when glyphosate is compartmentalized into vacuoles or trichomes of leaves close to the area where it was applied, or by altered activity of active membrane transporters $[16,35]$. Among the NTSR mechanisms, reduced glyphosate translocation is the most reported mechanism endowing resistance to this herbicide [30,32,36,37], which appears to be regulated by a single incompletely dominant nuclear gene [38]. Moreover, reduced absorption and translocation of ${ }^{14} \mathrm{C}$-glyphosate sometimes work in concert [16]; therefore, these two NTSR mechanisms contributed to the overall resistance of the R saltmarsh aster plants. At least one population of every glyphosate resistant weed species found in citrus groves from Mexico showed some of these NTSR mechanisms [19,20,26,39,40].

The population $\mathrm{R}$ of saltmarsh aster metabolized a greater amount of glyphosate in less time than the population S. Glyphosate metabolism as a resistance mechanism was first reported in Digitaria insularis determined by analytical techniques [41]. This finding generated controversy for not demonstrating its occurrence through molecular studies [20]. In addition, previously it had been concluded that weeds were unlikely to degrade glyphosate [42]. However, the enzyme aldo-keto reductase from glyphosate-resistant Echinochloa colona was recently found, following analytical and molecular approaches, capable of metabolizing glyphosate into AMPA and glyoxylate [43]. Although the work of Pan et al. [43] proved that metabolism may contribute in the resistance to glyphosate, it is presumed that this is not the main resistance mechanism in E. colona [18,44], since both $\mathrm{R}$ and $\mathrm{S}$ populations metabolized the herbicide. This observation is based on the fact that the transgenic canola plants to which the bacterial GOX (glyphosate oxidoreductase) gene was inserted, although they metabolize glyphosate, it was not enough to survive field applications [41,43]. Although the S population of E. colona metabolized $44 \%$ of the glyphosate, while the R population up to $90 \%$ of the herbicide at 72 HAT [43], McElroy and Hall [44] suggested that resistance in E. colona is based on a TSR mechanism (Pro106-Thr mutation), which was obfuscated because E. colona is a polyploid species. In the case of saltmarsh aster, the $S$ and R populations metabolized 27 and $50 \%$ of glyphosate, respectively, at $72 \mathrm{HAT}$, and up to 36 and $72 \%$ at $96 \mathrm{HAT}$, i.e., glyphosate metabolism was lower and slower than in E. colona. Therefore, this mechanism possibly contributes to the glyphosate resistance of the $\mathrm{R}$ saltmarsh aster population, but it is difficult to measure the magnitude of its contribution or to affirm that it performs a significant role [42]. However, it is necessary to deepen studies on candidate enzyme genes involved in the metabolism of this herbicide, since it seems that this mechanism is capable of conferring resistance to glyphosate [45]. 


\section{Materials and Methods}

\subsection{Biological Material}

Mature seeds of the $\mathrm{R}$ saltmarsh aster population were harvested in a Persian lime grove in the municipality of San Rafael, Veracruz, Mexico $\left(20^{\circ} 06^{\prime} 28^{\prime \prime} \mathrm{N}, 97^{\circ} 09^{\prime} 34^{\prime \prime} \mathrm{W}\right)$ from were collected from surviving adult plants (minimum 50) in the field at the last application of glyphosate at the recommended time and rate $\left(720 \mathrm{~g} \mathrm{ae} \mathrm{ha}^{-1}\right)$. Lime trees had a 15-year history of continuous glyphosate use (3-4 applications per year). Seeds from a never-treated population (S) were collected from a nearby grove where the R population was also obtained. The pool of seeds from an orchard constituted a sample of a single $R$ and $\mathrm{S}$ population.

The seeds were sown in trays $(15 \times 15 \times 8 \mathrm{~cm})$ on wet substrate (peat at field capacity) hermetically closed until germination and placed in a growth chamber at $26 / 18{ }^{\circ} \mathrm{C}$ (day/night), 16-h photoperiod at $850 \mathrm{\mu mol}^{-2} \mathrm{~s}^{-1}$ of light intensity and $60 \%$ of RH. Seedlings with two true leaves were individualized into $250-\mathrm{mL}$ punnet pots containing sand/peat $(1: 1, v / v)$ fertilized with $400 \mathrm{mg}$ of NPK $17-09-11+2 \% \mathrm{MgO}$. The pots were maintained in the growth chamber conserved the growing conditions until herbicide treatments. Plants were watered daily or as needed.

\subsection{Dose-Response Curves}

The tests were conducted on whole plants with 4 to 6 true leaves of the R and S populations. The doses of glyphosate (Roundup Energy $450 \mathrm{~g} \mathrm{~L}^{-1}$, Bayer Spain) sprayed on the population $S$ were $16.125,31.25,62.5,125,250,500$ and $1000 \mathrm{~g}^{a e ~ h a}{ }^{-1}$, while for the population $\mathrm{R}$ they were $65,125,250,500,1000,2000$ and $3000 \mathrm{~g}$ ae ha ${ }^{-1}$. Ten plants taken randomly from the corresponding population were treated per herbicide dose. Spraying was performed in an herbicide spray cabinet (SBS-060 De Vries Manufacturing, Hollandale, MN, United States). The cabinet application bar had an XR8002E tip and was calibrated to spray $200 \mathrm{~L} \mathrm{ha}^{-1}$ at a pressure of $250 \mathrm{kPa}$.

Four weeks after treatment (WAT), the aerial plant tissue was cut at ground level, conditioned in and identified in paper envelopes, and dried for 4 days at $60^{\circ} \mathrm{C}$. Then, samples were weighed and transformed into dry weight percentage to the $\mathrm{GR}_{50}$ with respect to the untreated control. Additionally, plant mortality per dose was assessed to determine $\mathrm{LD}_{50}$ values. The experiments were repeated twice, once in June 2019 and the second in January 2020.

\subsection{Shikimic Acid Accumulation}

For each population of saltmarsh aster, approximately 25 fully extended young leaves were taken from at least 15 plants with 4 to 6 true leaves and 4-mm diameter discs were cut. Samples of $50 \mathrm{mg}$ leaf discs (pool foliar tissue) were placed in 2-mL tubes containing $1 \mathrm{~mL}$ of $10-\mathrm{mM}$ ammonium phosphate monobasic solution ( $\mathrm{pH}$ adjusted to 4.4 with $0.1 \mathrm{HCl}$ ) at different rates of glyphosate $(0,100,250,500,1000$, and $2000 \mu \mathrm{M})$. The extraction of shikimic acid and quantification was performed according to Shaner et al. [24] with small adaptations [46]. Three samples of each saltmarsh aster population were assessed per glyphosate concentration. The experiment was completely randomized and was repeated twice. Results were expressed as micrograms of shikimate per $\mathrm{mL} \mathrm{HCl}$ solution ( $\mu \mathrm{g}$ shikimic acid $\mathrm{mL}^{-1}$ ) in relation to a calibration curve of shikimic acid.

\subsection{Enzymatic Activity of EPSPS}

Samples of 10-g fresh leaf tissue of each saltmarsh aster population were collected and immediately macerated in liquid $\mathrm{N}_{2}$ until obtaining a fine powder. After an extraction step, following the procedures detailed by Dayan et al. [27], samples were dialyzed in a 1000-MWC dialysis tubing $(30 \mathrm{~mm})$ at $4{ }^{\circ} \mathrm{C}$ on a stir plate over $12 \mathrm{~h}$. The protein concentration (basal activity) without glyphosate was determined by the Bradford method. Then, the EPSPS enzymatic activity of the $S$ and $R$ populations was assayed using a phosphate assay kit (EnzCheck, Invitrogen, Carlsbad, CA, USA) according to the manufacturer guidelines. 
Phosphoenolpyruvate $(1.02 \mathrm{mM})$ and shikimate-3-phosphate $(0.41 \mathrm{mM})$ were the substrates to check EPSPS activities under different glyphosate concentrations $(0,0.001,0.1,1,10,100$, 1000 and $5000 \mu \mathrm{M})$. The EPSPS activity was determined by measuring the amount ( $\mu \mathrm{mol})$ of Pi released per $\mu \mathrm{g}$ of TSP per min during $10 \mathrm{~min}$ at $360 \mathrm{~nm}$ in a spectrophotometer [26]. These tests were repeated twice evaluating three samples by glyphosate concentration and population, and for each sample three technical replicates were evaluated. The rate of glyphosate required to inhibit the EPSPS activity by $50 \%\left(\mathrm{I}_{50}\right)$ was determined.

\section{5. ${ }^{14}$ C-Glyphosate Absorption and Translocation}

${ }^{14} \mathrm{C}$-glyphosate [glycine-2- ${ }^{14} \mathrm{C}$, specific activity $273.8 \mathrm{MBq} \mathrm{mmol}^{-1}$, Institute of Isotopes Co. Ltd. Budapest, Hungary) was mixed with commercially formulated glyphosate.

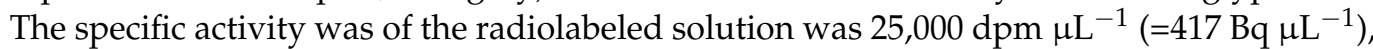
and the rate of glyphosate was $720 \mathrm{~g} \mathrm{ae} \mathrm{ha}{ }^{-1}$ in $200 \mathrm{~L} \mathrm{ha}^{-1}$. The second leaf was identified and protected with aluminum film. After this, plants were treated with glyphosate $(720 \mathrm{~g}$ ae $\mathrm{ha}^{-1}$ ), and $30 \mathrm{~min}$ later, the aluminum layer was removed [47]. The labeled herbicide solution was applied to the adaxial surface of the second leaf, that had been protected with aluminum layer, of 25 plants of each saltmarsh aster population in four $0.5 \mu \mathrm{L}$ droplets with a PB-600 repeating dispenser (Hamilton Company, Reno, NV, USA), i.e., each plant received a total of 50,000 dpm. The treated area of $R$ and $S$ populations was washed in sets of three plants at different intervals $(12,24,48,72$, and 96 HAT) to recover the unabsorbed ${ }^{14} \mathrm{C}$-glyphosate with $1.5 \mathrm{~mL}$ of acetone three times each plant. Three $\mathrm{mL}$ liquid scintillation cocktail (Ultima Gold, Perkin-Elmer, BV BioScience Packard, Waltham, MA, USA) was added to each wash sample and analyzed by LSS for $10 \mathrm{~min}$.

To determine the translocation rates of ${ }^{14} \mathrm{C}$-glyphosate, the whole plants were removed from the punnet pots, and the roots were carefully washed and dried and fixed on paper. Plants were dried at $60{ }^{\circ} \mathrm{C}$ for $4 \mathrm{~d}$ and then placed adjacent to a phosphorus storage film (Storage Phosphor System: Cyclone, Perkin-Elmer Packard BioScience BV) for $10 \mathrm{~h}$ in the dark. ${ }^{14} \mathrm{C}$-glyphosate distribution within plants was scanned in a phosphor storage system (Cyclone Plus, Perkin-Elmer). Then, plants were sectioned into treated leaves, the rest of the plants, and roots and burned in a sample oxidizer (Packard 307) for $3 \mathrm{~min}$. Released ${ }^{14} \mathrm{CO}_{2}$ was captured in $14 \mathrm{~mL}$ of Carbosorb/Permafluor E+ (7/7 v/v; Perkin-Elmer), and radioactivity was quantified by LSS by $10 \mathrm{~min}$. Mass balance (recovery percentage of ${ }^{14} \mathrm{C}$-glyphosate) and the rates of absorption (from total applied) and translocation (from recovered) were calculated according to Alcántara-de la Cruz et al. [34].

\subsection{Glyphosate Metabolism}

Saltmarsh aster plants at the 4-6 leaf stage of both populations were treated with $720 \mathrm{~g}$ ae ha ${ }^{-1}$ under the spraying conditions used in "dose-response curves". At 48, 72 and 96 HAT, the above ground tissue was harvested, washed, and macerated in liquid $\mathrm{N}_{2}$ and prepared for extraction according to Rojano-Delgado et al. [48]. The extracted samples were analyzed by reversed polarity capillary electrophoresis in a 3D Capillary Electrophoresis Agilent G1600 equipped with a diode array detector (DAD, wavelength range $190-600 \mathrm{~nm}$ ), using a background electrolyte of $10 \mathrm{mM}$ potassium phthalate, $0.5 \mathrm{mM}$ hexadecyltrimethylammonium bromide (CTAB) and $10 \%$ acetonitrile at $\mathrm{pH} 7.5$. Calibration curves of glyphosate, AMPA and glyoxylate of analytical grade (purity $<95 \%$, SigmaAldrich, Spain) were used for their quantification. In addition, the glyoxylate naturally produced by the plants was measured in nontreated plants and subtracted from the average found in glyphosate treated plants [48], i.e., the amount of glyoxylate reported correspond to that presumably from glyphosate metabolism. The experiment was repeated two times, with five replicates per population and evaluation time.

\subsection{Statistical Analysis}

The $\mathrm{GR}_{50}, \mathrm{LD}_{50}$ and $\mathrm{I}_{50}$ values of each saltmarsh aster population were determined by submitting the percentage data of dry weight reduction, plant survival and enzyme activity, 
respectively, to a nonlinear regression analysis using the three-parameter log-logistic model: $\mathrm{Y}=\left(d /\left[1+(x / g)^{b}\right]\right)[49]$. Regression analyses were performed on SigmaPlot 11. After this, the resistance factors $(R F=R / S)$ of each parameter $\left(G_{50}, L_{50}\right.$ or $\left.I_{50}\right)$ were calculated.

Data obtained from the shikimic acid accumulation, EPSPS basal activity, absorption, translocation and metabolism of glyphosate were analyzed by one-way ANOVA. When necessary, Tukey's HSD test (95\% confidence level) was used to separate the means.

\section{Conclusions}

This study confirmed glyphosate resistance in saltmarsh aster collected in citrus groves from the Gulf Coast of Mexico. Resistance is endowed by three non-target site mechanisms: reduced absorption, impaired translocation and metabolism of glyphosate. The combination of these mechanisms allows $\mathrm{R}$ aster individuals to survive and regrow vigorously after having suffered a severe growth arrest caused by glyphosate. The results of this work report the first case of glyphosate resistance in Aster squamatus, and it is the sixth species to evolve resistance to this herbicide in citrus groves from Mexico.

Author Contributions: Conceptualization, J.A.D.-V. and R.D.P.; investigation, collection, curation and analysis of the data, J.A.D.-V., R.A.-d.1.C., J.G.V.-G., C.P.-B., H.E.C.-H., R.D.P.; writing-original draft, review and editing, J.A.D.-V., R.A.-d.I.C., J.G.V.-G., C.P.-B., H.E.C.-H., R.D.P.; writing-review and editing, R.A.-d.l.C.; resources and supervision, J.A.D.-V., H.E.C.-H. and R.D.P.; funding acquisition, J.A.D.-V. and R.D.P. All authors have read and agreed to the published version of the manuscript.

Funding: This work was funded by the Asociación de Agroquímicos y Medioambiente and the Universidad Autónoma Chapingo.

Institutional Review Board Statement: Not applicable.

Informed Consent Statement: Not applicable.

Data Availability Statement: Not applicable.

Conflicts of Interest: The authors declare no conflict of interest.

\section{References}

1. Antier, C.; Kudsk, P.; Reboud, X.; Ulber, L.; Baret, P.; Messéan, A. Glyphosate use in the European agricultural sector and a framework for its further monitoring. Sustainability 2020, 12, 5682. [CrossRef]

2. Gravena, R.; Filho, R.V.; Alves, P.L.C.A.; Mazzafera, P.; Gravena, A.R. Glyphosate has low toxicity to citrus plants growing in the field. Can. J. Plant Sci. 2012, 92, 119-127. [CrossRef]

3. Woodburn, A.T. Glyphosate: Production, pricing and use worldwide. Pest Manag. Sci. 2000, 56, 309-312. [CrossRef]

4. Alcántara-de la Cruz, R.; Domínguez-Martínez, P.A.; Silveira, H.M.; Cruz-Hipólito, H.E.; Palma-Bautista, C.; Vázquez-García, J.G.; Domínguez-Valenzuela, J.A.; De Prado, R. Management of glyphosate-resistant weeds in Mexican citrus groves: Chemical alternatives and economic viability. Plants 2019, 8, 325. [CrossRef] [PubMed]

5. SADER-SIAP. Anuario Estadístico De La Producción Agrícola. 2019. Available online: https://nube.siap.gob.mx/cierreagricola/ (accessed on 26 February 2021).

6. FAOSTAT. Crops. 2021. Available online: http://www.fao.org/faostat/en/?\#data/QC (accessed on 26 February 2020).

7. USDA-U.S. Department of Agriculture. Citrus: World Markets and Trade. 2021. Available online: https://apps.fas.usda.gov/ psdonline/circulars/citrus.pdf (accessed on 1 April 2021).

8. Pérez-López, M.; González-Torralva, F.; Cruz-Hipólito, H.; Santos, F.; Domínguez-Valenzuela, J.A.; De Prado, R. Characterization of glyphosate-resistant tropical sprangletop (Leptochloa virgata) and its alternative chemical control in persian lime orchards in Mexico. Weed Sci. 2014, 62, 441-450. [CrossRef]

9. Alcántara-de la Cruz, R.; Cruz-Hipolito, H.E.; Domínguez-Valenzuela, J.A.; De Prado, R. Glyphosate ban in Mexico: Potential impacts on agriculture and weed management. Pest Manag. Sci. 2021, 77, 3820-3831. [CrossRef] [PubMed]

10. Troiani, H.O.; Steibel, P.E. Synopsis of the compositae giseke of La Pampa, Argentina. Rev. Fac. Agron. 1998, 9, 1-86.

11. CABI. Symphyotrichum Subulatum Var. Squamatum. 2019. Available online: https://www.cabi.org/cpc/datasheet/120910 (accessed on 2 February 2021).

12. Nesom, G.L. Taxonomy of the Symphyotrichum (Aster) subulatum group and Symphyotrichum (Aster) tenuifolium (Asteraceae: Astereae). SIDA Contrib. Bot. 2005, 21, 2125-2140.

13. Heap, I. The International Survey of Herbicide Resistant Weeds. 2021. Available online: www.weedscience.org (accessed on 10 February 2021). 
14. Gaines, T.A.; Patterson, E.L.; Neve, P. Molecular mechanisms of adaptive evolution revealed by global selection for glyphosate resistance. New Phytol. 2019, 223, 1770-1775. [CrossRef]

15. Dayan, F.E.; Barker, A.; Takano, H.; Bough, R.; Ortiz, M.; Duke, S.O. Herbicide mechanisms of action and resistance. In Comprensive Biotechnology Vol. 4, 3rd ed.; Moo-Young M, Ed.; Pergamon: Oxford, UK, 2019; pp. 36-48.

16. Gaines, T.A.; Duke, S.O.; Morran, S.; Rigon, C.A.G.; Tranel, P.J.; Küpper, A.; Dayan, F.E. Mechanisms of evolved herbicide resistance. J. Biol. Chem. 2020, 295, 10307-10330. [CrossRef]

17. Osuna, M.D.; Fischer, A.J.; De Prado, R. Herbicide resistance in Aster squamatus conferred by a less sensitive form of acetolactate synthase. Pest Manag. Sci. 2003, 59, 1210-1216. [CrossRef]

18. Duke, S.O. Enhanced metabolic degradation: The last evolved glyphosate resistance mechanism of weeds? Plant Physiol. 2019, 181, 1401-1403. [CrossRef]

19. La Cruz, R.A.-D.; Fernández-Moreno, P.T.; Ozuna, C.V.; Rojano-Delgado, A.M.; Cruz-Hipolito, H.E.; Valenzuela, J.A.D.; Barro, F.; De Prado, R. Target and non-target site mechanisms developed by glyphosate-resistant hairy beggarticks (Bidens pilosa L.) populations from Mexico. Front. Plant Sci. 2016, 7, 1492.

20. Palma-Bautista, C.; Gherekhloo, J.; Domínguez-Martínez, P.A.; Domínguez-Valenzuela, A.; Cruz-Hipolito, H.E.; Alcántara-de la Cruz, R.; Rojano-Delgado, A.M.; De Prado, R. Characterization of three glyphosate resistant Parthenium hysterophorus populations collected in citrus groves from Mexico. Pestic. Biochem. Physiol. 2019, 155, 1-7. [CrossRef]

21. Moretti, M.L.; Van Horn, C.R.; Robertson, R.; Segobye, K.; Weller, S.C.; Young, B.G.; Johnson, W.G.; Sammons, R.D.; Wang, D.; $\mathrm{Ge}, \mathrm{X}$; i et al. Glyphosate resistance in Ambrosia trifida: Part 2. Rapid response physiology and non-target-site resistance. Pest Manag. Sci. 2018, 74, 1079-1088. [CrossRef]

22. Van Horn, C.R.; Moretti, M.L.; Robertson, R.R.; Segobye, K.; Weller, S.C.; Young, B.G.; Johnson, W.; Schulz, B.; Green, A.C.; Jeffery, T.; et al. Glyphosate resistance in Ambrosia trifida: Part 1. Novel rapid cell death response to glyphosate. Pest Manag. Sci. 2018, 74, 1071-1078. [CrossRef]

23. De Queiroz, A.R.S.; Delatorre, C.A.; Lucio, F.R.; Rossi, C.V.S.; Zobiole, L.H.S.; Merotto, A. Rapid necrosis: A novel plant resistance mechanism to 2,4-D. Weed Sci. 2020, 68, 6-18. [CrossRef]

24. Shaner, D.L.; Nadler-Hassar, T.; Henry, W.B.; Koger, C.H. A rapid in vivo shikimate accumulation assay with excised leaf discs. Weed Sci. 2005, 53, 769-774. [CrossRef]

25. Maeda, H.; Dudareva, N. The shikimate pathway and aromatic amino acid biosynthesis in plants. Annu. Rev. Plant Biol. 2012, 63, 73-105. [CrossRef] [PubMed]

26. Bracamonte, E.; Silveira, H.M.; Alcántara-de la Cruz, R.; Domínguez-Valenzuela, J.A.; Cruz-Hipolito, H.E.; De Prado, R. From tolerance to resistance: Mechanisms governing the differential response to glyphosate in Chloris barbata. Pest Manag Sci. 2018, 74, 1118-1124. [CrossRef] [PubMed]

27. Dayan, F.E.; Owens, D.K.; Corniani, N.; Silva, F.M.L.; Watson, S.B.; Howell, J.; Shaner, D.L. Biochemical markers and enzyme assays for herbicide mode of action and resistance studies. Weed Sci. 2015, 63, 23-63. [CrossRef]

28. Cruz-Hipolito, H.; Rojanodelgado, A.M.; Valenzuela, J.A.D.; Heredia, A.; de Castro, M.D.L.; De Prado, R. Glyphosate tolerance by Clitoria ternatea and Neonotonia wightii plants involves differential absorption and translocation of the herbicide. Plant Soil 2011, 347, 221-230. [CrossRef]

29. Menendez, J.; Rojano-Delgado, M.A.; De Prado, R. Differences in herbicide uptake, translocation, and distribution as sources of herbicide resistance in weeds. In Retention, Uptake, and Translocation of Agrochemicals in Plants, 1st ed.; Myung, K., Satchivi, N.M., Kingston, C.K., Eds.; ACS Publications: Washington, DC, USA, 2014; pp. 141-157.

30. Nandula, V.K.; Ray, J.D.; Ribeiro, D.N.; Pan, Z.; Reddy, K.N. Glyphosate resistance in tall waterhemp (Amaranthus tuberculatus) from Mississippi is due to both altered target-site and nontarget-site mechanisms. Weed Sci. 2013, 61, 374-383. [CrossRef]

31. Michitte, P.; De Prado, R.; Espinoza, N.; Ruiz-Santaella, J.P.; Gauvrit, C. Mechanisms of resistance to glyphosate in a ryegrass (Lolium multiflorum) biotype from Chile. Weed Sci. 2007, 55, 435-440. [CrossRef]

32. Vila-Aiub, M.M.; Balbi, M.C.; Distéfano, A.J.; Fernandez, L.; Hopp, H.E.; Yu, Q.; Powles, S.B. Glyphosate resistance in perennial Sorghum halepense (Johnsongrass), endowed by reduced glyphosate translocation and leaf uptake. Pest Manag. Sci. 2012, 68, 430-436. [CrossRef] [PubMed]

33. Svyantek, A.W.; Aldahir, P.; Chen, S.; Flessner, M.L.; McCullough, P.E.; Sidhu, S.S.; McElroy, J.S.; Aldahir, P. Target and nontarget resistance mechanisms induce annual bluegrass (Роа annua) resistance to atrazine, amicarbazone, and diuron. Weed Technol. 2016, 30, 773-782. [CrossRef]

34. De La Cruz, R.A.; Amaral, G.D.S.; Mendes, K.F.; Rojano-Delgado, A.M.; De Prado, R.; Silva, M.F.D.G.F.D. Absorption, translocation, and metabolism studies of herbicides in weeds and crops. In Radioisotopes in Weed Research, 1st ed.; Mendes, K.F., Ed.; CRC Press: Boca Raton, FL, USA, 2021; pp. 127-154.

35. Ge, X.; d'Avignon, D.A.; Ackerman, J.J.H.; Sammons, D.R. Rapid vacuolar sequestration: The horseweed glyphosate resistance mechanism. Pest Manag. Sci. 2010, 66, 345-348. [CrossRef]

36. Kleinman, Z.; Rubin, B. Non-target-site glyphosate resistance in Conyza bonariensis is based on modified subcellular distribution of the herbicide. Pest Manag. Sci. 2017, 73, 246-253. [CrossRef]

37. Palma-Bautista, C.; Torra, J.; Garcia, M.J.; Bracamonte, E.; Rojano-Delgado, A.M.; la Cruz, R.A.-D.; De Prado, R. Reduced absorption and impaired translocation endows glyphosate resistance in Amaranthus palmeri harvested in glyphosate-resistant soybean from Argentina. J. Agric. Food Chem. 2019, 67, 1052-1060. [CrossRef] 
38. Ghanizadeh, H.; Harrington, K.C. Restricted glyphosate translocation in Lolium multiflorum is controlled by a single incomplete dominant nuclear gene. N. Z. J. Crop Hortic. Sci. 2018, 46, 346-353. [CrossRef]

39. La Cruz, R.A.-D.; Rojano-Delgado, A.M.; Giménez, M.J.; Cruz-Hipolito, H.E.; Domínguez-Valenzuela, J.A.; Barro, F.; De Prado, R. First resistance mechanisms characterization in glyphosate-resistant Leptochloa virgata. Front. Plant Sci. 2016, 7, 1742.

40. Gherekhloo, J.; Fernández-Moreno, P.T.; La Cruz, R.A.-D.; Sánchez-González, E.; Cruz-Hipolito, H.E.; Domínguez-Valenzuela, J.A.; De Prado, R. Pro-106-Ser mutation and EPSPS overexpression acting together simultaneously in glyphosate-resistant goosegrass (Eleusine indica). Sci. Rep. 2017, 7, 6702. [CrossRef] [PubMed]

41. De Carvalho, L.B.; Alves, P.L.D.C.A.; González-Torralva, F.; Cruz-Hipolito, H.E.; Rojano-Delgado, A.M.; De Prado, R.; Gil Humanes, J.; Barro, F.; De Castro, M.D.L. Pool of resistance mechanisms to glyphosate in Digitaria insularis. J. Agric. Food Chem. 2012, 60, 615-622. [CrossRef]

42. Duke, S.O. Glyphosate degradation in glyphosate-resistant and -susceptible crops and weeds. J. Agric. Food Chem. 2011, 59, 5835-5841. [CrossRef] [PubMed]

43. Pan, L.; Yu, Q.; Han, H.; Mao, L.; Nyporko, A.; Fan, L.; Bai, L.; Powles, S. Aldo-keto reductase metabolizes glyphosate and confers glyphosate resistance in Echinochloa colona. Plant Physiol. 2019, 181, 1519-1534. [CrossRef] [PubMed]

44. McElroy, J.S.; Hall, N.D. Echinochloa colona with reported resistance to glyphosate conferred by aldo-keto reductase also contains a pro-106-Thr EPSPS target site mutation. Plant Physiol. 2020, 183, 447-450. [CrossRef]

45. Baek, Y.; Bobadilla, L.K.; Giacomini, D.A.; Montgomery, J.S.; Murphy, B.P.; Tranel, P.J. Evolution of glyphosate-resistant weeds. In Reviews of Environmental Contamination and Toxicology; Springer: New York, NY, USA, 2021; pp. 1-36. [CrossRef]

46. Palma-Bautista, C.; Tahmasebi, B.K.; Fernández-Moreno, P.T.; Rojano-Delgado, A.M.; Alcántara de la Cruz, R.; De Prado, R. First Case of Conyza canadensis from Hungary with Multiple Resistance to Glyphosate and Flazasulfuron. Agronomy 2018, 8, 157. [CrossRef]

47. Yanniccari, M.; Vázquez-García, J.G.; Gómez-Lobato, M.E.; Rojano-Delgado, A.M.; Alves, P.L.D.C.A.; De Prado, R. First case of glyphosate resistance in Bromus catharticus Vahl.: Examination of endowing resistance mechanisms. Front. Plant Sci. 2021, 12, 617945. [CrossRef]

48. Rojano-Delgado, A.M.; Ruiz-Jiménez, J.; De Castro, M.D.L.; De Prado, R. Determination of glyphosate and its metabolites in plant material by reversed-polarity CE with indirect absorptiometric detection. Electrophoresis 2010, 31, 1423-1430. [CrossRef]

49. Ritz, C.; Baty, F.; Streibig, J.C.; Gerhard, D. Dose-response analysis using R. PLoS ONE 2015, 10, e0146021. [CrossRef] [PubMed] 